The Effect Of Use Of Audio Visual Media...

\title{
THE EFFECT OF USE OF AUDIO VISUAL MEDIA ON RESULTS OF STUDY ON SOCIAL KNOWLEDGE SCIENCE IN MADRASAH
}

\author{
Siti Khoiriyah \\ Moh Sutomo \\ IAIN Jember \\ khoiriyah181@gmail.com
}

\begin{abstract}
Social Sciences is an integration from various branches namely history, geography, economy, sociology and anthropology which are simplified and formulated for instructional purposes and completed with material and objectives so that they are easy to learn at the public/Islamic elementary school and public/Islamic junior high school levels. With the complexity of Social Sciences studies, effective and efficient media for learning activities are needed. So, it is very necessary for a teacher to use interesting media in the teaching and learning process. One of the interesting media can be used is audio-visual media as a means of motivating and increasing effectiveness and efficiency in achieving student learning outcomes.

The purpose of this study is to examine the influence of the use of audio-visual media on student learning outcomes in social studies subjects at the Madrasah Tsanawiyah ASHRI Jember in the academic year 2019/2020.

This study, used a quantitative approach with a quasi-experimental type of research, and applied a non-equivalent control group design. The population of this study was students of class VIII ASHRI Madrasah Jember. The research sample obtained through purposive sampling technique, which amounted to 74 students consisting of class VIII $A$ as an experimental class and VIII B as a control class. Documentation in the form of post test scores was used as the data collection analysis. Analysis and test of hypotheses were done with Independent Sample T-Test and the assistance of the IBM SPSS 22.00 For Windows.

By using Independent Sample T-Test as the hypothesis testing, the results of this study indicated the significance of 0,000 (2-tailed). This showed that the significance value was under 0.05, so that the null hypothesis $\left(\mathrm{H}_{0}\right)$ was rejected and the alternative hypothesis $\left(\mathrm{H}_{2}\right)$ was accepted. This means that there is a significant influence on the use of audio-visual learning media on the learning outcomes of Social Sciences subject at the Madrasah Tsanawiyah ASHRI Jember in the academic year 2019/2020.
\end{abstract}

Keywords: audio-visual media, learning outcomes

\begin{abstract}
Abstrak
Ilmu Pengetahuan Sosial merupakan integrasi dari berbagai cabang ilmu sosial yakni sejarah, geografi, ekonomi, sosiologi dan antropologi yang diformulasikan untuk tujuan instruksional dengan materi dan tujuan yang disederhanakan agar mudah dipelajar pada jenjang SD/MI, dan SMP/MTs. Dengan kompleksitas kajian Ilmu Pengetahuan Sosial maka dibutuhkan media yang efektif dan efisien untuk kegiatan pembelajaran. Maka sangatlah perlu untuk seorang guru dalam proses belajar mengajar menggunakan media yang menarik, salah

Falasifa, Vol. 11 Nomor 1 Maret 2020 | 157
\end{abstract}


Siti Khoiriyah

Moh Sutomo

satunya adalah audio visual yang berfungsi sebagai sarana memotivasi dan meningkatkan efektifitas dan efisiensi dalam pencapaian hasil belajar siswa.

Tujuan penelitian ini adalah untuk menguji ada tidaknya pengaruh penggunaan media audio visual terhadap hasil belajar siswa pada mata pelajaran IPS di Madrasah Tsanawiyah ASHRI Jember tahun pelajaran 2019/2020.

Penelitian yang dirancang dengan pendekatan kuantitatif dengan jenis penelitian quasi experimental ini didesain dengan menggunakan non-equivalent control group design. Populasi penelitian ini adalah siswa kelas VIII Madrasah ASHRI Jember, sedangkan sampel penelitian dengan teknik purposive sampling berjumlah 74 siswa terdiri dari kelas VIII A sebagai kelas eksperimen dan VIII B sebagai kelas kontrol. Teknik pengumpulan data menggunakan dokumentasi berupa nilai posttest. Analisis dan uji hipotesis dengan Independent Sample TTest dan dilakukan bantuan program IBM SPSS 22.00 For Windows.

Hasil penelitian ini menunjukkan hasil uji hipotesis dengan menggunakan uji Independent Sample T-Test diperoleh nilai Sig. (2-tailed) sebesar 0,000. Hal ini menunjukkan bahwa nilai signifikansi atau Sig. (2-tailed) $<0,05$ sehingga hipotesis nihil $\left(\mathrm{H}_{0}\right)$ ditolak dan hipotesis alternatif $\left(\mathrm{H}_{2}\right)$ diterima. Artinya ada pengaruh yang signifikan penggunaan media pembelajaran audio visual terhadap hasil belajar Ilmu Pengetahuan Sosial di Madrasah Tsanawiyah ASHRI Jember tahun pelajaran 2019/2020.

Kata kunci : media audio visual, hasil belajar

\section{PENDAHULUAN}

Efek perkembangan ilmu pengetahuan dan teknologi telah mendorong upaya pembaruan dalam pemanfaatan hasil-hasil teknologi dalam proses belajar termasuk media pembelajaran. Guru sebagai fasilitator dalam proses pembelajaran harus mampu memastikan bahwa teknologi media pembelajraan yang disediakan oleh sekolah sesuai dengan perkembangan dan tuntutan zaman. Media pembelajaran yang digunakan memang sekurangkurangnya alat yang murah dan efisien serta sederhana dan bersahaja, tetapi dapat diupayakan efektif mencapai tujuan pengajaran yang diharapkan. ${ }^{1}$

Proses belajar mengajar atau proses pengajaran merupakan suatu kegiatan dari pelaksanaan kurikulum suatu lembaga pendidikan untuk mencapai tujuan pendidikan yang telah ditetapkan. ${ }^{2}$ Proses belajar yang diperlukan saat ini adalah pembelajaran yang inovatif, interaktif, menyenangkan, memotivasi dan menanntang yang salah satunya memerlukan upaya mengembangkan media pembelajaran dalam kelas. Media pembelajaran yang dikembangkan

\footnotetext{
${ }^{1}$ Ashar Arsyad, 2013, Media Pembelajaran. (Jakarta : PT Raja Grafindo Persada), 1-2

${ }^{2}$ Sudjana dan Rivai, 2001, Media Pengajaran (Bandung: Sinar Baru Algen Sindo), 1

158 | Falasifa, Vol. 11 Nomor 1 Maret 2020
} 
harus mampu meningkatkan motivasi dan merangsang siswa. Media peembelajaran yang baik akan mengaktifkan siswa dalam memberikan tanggapan, umpan balik, dan mendorong siswa untuk melakukan praktik-praktik yang benar.

Media pembelajaran konvensional sering diidentikkan dengan media yang sering digunakan dalam proses pembelajaran secara umum dan turun temurun. Media ini sering digunakan guru karena persiapannya paling mudah, sederhana tetapi cenderung juga membuat siswa bosan karena hanya terjadi interaksi satu arah saja yaitu dari guru kepada siswa. Contoh media konvensional yang banyak digunakan adalah papan tulis ataupun gambar yag dipampang di dinding kelas. Penggunaan media pembelajaran konvensional dalam pembelajaran memang kurang tepat, dan berdampak kurang optimal hasil belajar siswa. Proses pembelajaran yang kurang efektif merupakan faktor penyebab rendahnya hasil belajar dari penggunaan media pembelajaran kkonvensional.

Media Pembelajaran audio visual (AV) merupakan teknologi media pembelajaran yang mampu menghasilkan atau menyampaikan materi dengan menggunakan mesin-mesin mekanis dan elektronik untuk menyajikan pesan-pesan audio dan visual. Pengajaran melalui media audio-visual jelas bercirikan pemakaian perangkat keras selama proses belajar, seperti mesin proyektor film, tape recorder dan proyektor visual lebar. Jadi pengajaran melalui media audiovisual adalah produksi dan penggunaan materi yang penyerapannya melalui pandangan dan pendengaran serta tidak seluruhnya tergantung kepada pemahaman kata atau simbol-simbol yang serupa. ${ }^{3}$

Media pembelajaran audio-visual merupakan salah satu alternatif yang dapat digunakan sebagai media pembelajaran karena dapat memberi pandangan lebih terhadap materi yang akan disampaikan oleh guru kepada peserta didik. Disamping buku panduan dan modul, penyampaian materi menggunakan media audio-visual dirasa akan lebih menarik bagi peserta didik. Dengan begitu peserta didik diharapkan dapat lebih mengerti akan materi yang disampaikan oleh guru. Dengan demikian media pembelajaran audio-visual memberikan nilai lebih pada proses belajar mengajar yang dilakukan siswa dalam perolehan hasil belajar karena mampu menampilkan pesan yang bersifat audio dan juga visual.

\footnotetext{
${ }^{3}$ Azhar Arsyad, Media Pembelajaran (Jakarta : Rajawali Pers, 2014), 32
}

Falasifa, Vol. 11 Nomor 1 Maret 2020 | 159 
Siti Khoiriyah

Moh Sutomo

Hasil belajar merupakan indikator pencapaian target yang direncanakan dalam proses pembelajaran. Bagi guru hasil belajar tidak hanya menjadi indikator keberhasilan dalam menyampaikan materi kepada siswa melainkan juga menjadi indikator pengukuran efektif tidaknya metode dan juga media pembelajaran yang telah dikembangkan dalam proses pembalajaran. Oleh karena itu ukuran perolehan hasil belajar harus mampu memberikan informasi kepada guru sebagai pengembang pembelajaran tentang efektifitas dan efisiensi proses yang direncanakan dan dilaksanakan dalam bentuk pembelajaran. Hasil belajar selalu ditandai dengan perubahan yang terjadi pada siswa yang sedang belajar.

Ilmu Pengetahuan Sosial (IPS) sebagai mata pelajaran merupakan integrasi dari berbagai cabang ilmu-ilmu sosial, yaitu: sosiologi, sejarah, geografi, ekonomi, politik, hukum, dan budaya. IPS dirumuskan atas dasar realitas dan fenomena sosial yang mewujudkan satu pendekatan interdisipliner dari aspek dan cabang-cabang ilmu sosial ${ }^{4}$. Dengan demikian IPS memiliki kompleksitas dalam penyajian materi pembelajarannya, karena itu membutuhkan strategi dan pendekatan yang berbeda dengan mata pelajaran lainnya. Salah satu upaya tersebut adalah penggunaan media pembelajaran audio visual yang memang memiiki kelebihan dalan hal menyajikan materi pembelajaran, khususnya materi IPS. Maka sangatlah perlu untuk seorang guru dalam proses belajar mengajar menggunakan media yang menarik, salah satunya adalah audio visual yang berfungsi memotivasi dan meningkatkan hasil belajar siswa pada pelajaran IPS. Penggunaan media pembelajaran media audio-visual dalam pembelajaran IPS adalah upaya alternatif untuk membantu guru dalam penciptaan pengalaman belajar siswa, sehingga efektif dan efisien dalam proses pembelajaran.

\section{METODE}

Penelitian ini menggunakan pendekatan kuantitatif dengan jenis penelitian quasi experimental design yang didesain nonequivalen control group design.

Populasi dalam penelitian ini adalah seluruh siswa kelas VIII Madrasah Tsanawiyah ASHRI Jember yang terdiri dari 2 kelas yang berjumlah 74 siswa. Sampel diambil berdasarkan

\footnotetext{
${ }^{4}$ Ahmad Susanto, Teori Belajar dan Pembelajaran di Sekolah Dasar, (Jakarta : Kencana Prenada Media Group, 2013). Hal 6
}

160 | Falasifa, Vol. 11 Nomor 1 Maret 2020 
teknik purposive sampling yaitu kelas VIIIA sebagai kelas eksperimen dan kelas VIIIB sebagai kelas kontrol.

Teknik pengumpulan data yang digunakan adalah teknik dokumentasi. Teknik dokumentasi digunakan dalam penelitian ini untuk mengumpulkan data-data berupa nilai pretes dan posttes baik pada kelas eksperimen maupun kelas kontrol.

Instrumen yang digunakan dalam penelitian ini adalah instrumen tes yang berbentuk pilihan ganda. Tes dilakukan sebanyak dua kali yaitu pre-tes dan post-test. Pre-test dilakukan untuk mengetahui kemampuan awal siswa sebelum diberikan pembelajaran dengan menggunakan media Audio-Visual sedangkan post-test dilakukan untuk mengetahui kemampuan akhir siswa setelah diberikan perlakuan menggunakan media Audio-Visual, dan ada 25 soal untuk di kerjakan waktu pre-test dan post-tes. Analisis data menggunakan menggunakan uji $\mathrm{T}$, yang didahului dengan uji normalitas dan homogenitas dengan menggunakan bantuan program SPSS 22.00 for windows

\section{PEMBAHASAN}

Analisis uji T yang dilakukan untuk menganalisis data yang kemudian digunakan untuk menguji hipotesis nihil $\left(\mathrm{H}_{0}\right)$ yang diajukan peneliti yaitu : “Tidak pengaruh yang signifikan antara penggunaan media audio visual terhadap hasil belajar siswa pada mata pelajaran Ilmu Pengetahuan Sosial di Madrasah ASHRI Jember pada tahun pelajaran 2019/2020”.

Pengujian Independent Sample T test dalam penelitian ini dilakukan dengan bantuan IBM SPSS for Windows versi 22 menggunakan kriteria pengujian sebagai berikut: jika nilai signifikansi atau nilai sig. (2-tailed) $>0.05$ maka $\mathrm{H}_{0}$ diterima dan $\mathrm{H}_{\mathrm{a}}$ ditolak. Jika nilai signifikansi atau nilai sig. (2-tailed) $<0.05$ maka $\mathrm{H}_{0}$ ditolak dan $\mathrm{H}_{\mathrm{a}}$ diterima.

Adapun hasil uji Independent Sample T test dengan bantuan IBM SPSS for Windows versi 22 terhadap hasil belajar (posttes) pada kelas kontrol dan kelas eksperimen disajikan dalam tabel berikut:

Tabel 1.3 Hasil Uji T

Independent Samples Test

\begin{tabular}{|c|c|c|c|c|c|c|c|c|c|c|}
\hline & \multicolumn{2}{|c|}{$\begin{array}{c}\text { Levene's Test } \\
\text { for Equality of } \\
\text { Variances } \\
\end{array}$} & \multicolumn{7}{|c|}{ t-test for Equality of Means } \\
\hline & & \multirow[b]{2}{*}{$\mathrm{F}$} & \multirow[b]{2}{*}{ Sig. } & \multirow[b]{2}{*}{$\mathrm{T}$} & \multirow[b]{2}{*}{$\mathrm{df}$} & \multirow{2}{*}{$\begin{array}{l}\text { Sig. (2- } \\
\text { tailed) }\end{array}$} & \multirow{2}{*}{$\begin{array}{c}\text { Mean } \\
\text { Differen } \\
\text { ce }\end{array}$} & \multirow{2}{*}{$\begin{array}{c}\text { Std. } \\
\text { Error } \\
\text { Differe } \\
\text { nce }\end{array}$} & \multicolumn{2}{|c|}{$\begin{array}{l}\text { 95\% Confidence } \\
\text { Interval of the } \\
\text { Difference }\end{array}$} \\
\hline & & & & & & & & & Lower & Upper \\
\hline $\begin{array}{l}\text { Hasil } \\
\text { Belajar }\end{array}$ & $\begin{array}{l}\text { Equal } \\
\text { variances } \\
\text { assumed }\end{array}$ & 3,242 & ,076 & $-4,497$ & 72 & ,000 & $-11,054$ & 2,458 & $-15,954$ & $-6,154$ \\
\hline
\end{tabular}


Siti Khoiriyah

Moh Sutomo

Berdasarkan hasil uji t yang diperoleh dari tabel diatas bahwa nilai sig.(2-tailed) yaitu 0,000. Hal ini menunjukkan bahwa nilai signifikansi atau nilai sig (2-tailed) $<0,05$ sehingga hipotesis nihil $\left(\mathrm{H}_{0}\right)$ ditolak dan hipotesis alternative $\left(\mathrm{H}_{2}\right)$ diterima. Dengan ditolaknya $\mathrm{H}_{0}$ dan diterimanya $\mathrm{H}_{a}$ pada pengujian hipotesis tersebut, dapat disimpulkan bahwa terdapat pengaruh media audio visual terhadap hasil belajar Ilmu Pengetahuan Sosial di Madrasah Tsanawiyah ASHRI Jember tahun pelajaran 2019/2020. Secara sederhana dapat dikatakan bahwa terdapat pengaruh atau kontribusi penggunaan media audio visual terhadap hasil belajar Ilmu Pengetahuan Sosial. Media audio visual memang memiliki kelebihan dalam mendorong meningkatnya hasil belajar IPS, karena memang sajian IPS yang kompleksitas tersebut. Semakin seringnya digunakan media audio visual dalam pembelajaran IPS, memungkinkan siswa semakin mudah dalam memahami materi dan mendorong prestasi dalam belajar IPS lebih tinggi dibandingkan dengan tidak menggunakan medi audio visual.

Hasil penelitian diatas sesuai dengan hasil penelitian yang dilakukan Tenia Mudhia Khalistiana, dkk. Pada tahun 2015 yang berjudul "Pengaruh Penggunaan Media Audio-Visual Terhadap Hasil Belajar Siswa Kelas V Materi Keragaman Kenampakan Alam Dan Buatan Indonesia". Berdasarkan hasil uji rata-rata skor N-Gain diperoleh nilai signifikansi sebesar 0,002 (Sig. 2-tailed) dengan demikian nilai signifikansi one tailed tersebut dan nilai tersebut lebih kecil dari $0,005(0,002<0,05)$ sehingga $\mathrm{H}_{0}$ ditolak atau $\mathrm{H}_{\mathrm{a}}$ diterima. Hal ini berarti ada pengaruh yang signifikan Pengaruh Penggunaan Media Audio-Visual Terhadap Hasil Belajar Siswa Kelas V Materi Keragaman Kenampakan Alam Dan Buatan Indonesia. Dengan demikian pula dapat diuraikan secara signifikan peningkatan hasil belajar siswa dalam materi keragaman kenampakan alam dan buatan wilayah Indonesia dengan menggunakan media audio-visual lebih baik dibandingkan pada yang tidak menggunakan media audio-visual. ${ }^{5}$

Hal tersebut diperkuat lagi dengan penelitian yang sudah dilakukan oleh Nira Elphira dan Anik Gufron yang berjudul "Pengaruh Penggunaan Media Powerpoint Terhadap Minat Dan Hasil Belajar IPA Siswa Kelas IV SD”. Berdasarkan hasil yang diperoleh yakni terdapat pengaruh media Powerpoint terhadap minat belajar IPA siswa kelompok eksperimen pada

\footnotetext{
${ }^{5}$ Thenia Mudhia Khalistiana, dkk. "Pengaruh Penggunaan Media Audio-Visual Terhadap Hasil Belajar Siswa Kelas V Materi Keragaman Kenampakan Alam Dan Buatan Indonesia”. (Jurnal, Fakultas Ilmu Pendidikan, Universitas Pendidikan Indonesia, 2015 )
}

162 | Falasifa, Vol. 11 Nomor 1 Maret 2020 
pembelajaran yang menggunakan media Powerpoint. Minat belajar IPA siswa kelas IV SD Muhammadiyah Sagan meningkat 13,77 atau 11,48\%, yaitu dari hasil selisih rerataan sebelum pembelajaran 99,84 dengan hasil rerataan sesudah pembelajaran 113,61. Terdapat pengaruh media Powerpoint terhadap hasil belajar IPA siswa kelompok eksperimen pada pembelajaran yang menggunakan media Powerpoint. Hasil belajar IPA siswa kelas IV SD Muhammadiyah Sagan meningkat 14,01 atau 14,01\%, yaitu dari hasil selisih rerataan pretest 71,82 dengan hasil rerataan post-test $85,83{ }^{6}$ Hal ini memperlihatkan bahwa media visual memiliki keunggulan dibandingkan dengan media lainnya dalam medorong kemudahan dalam perolehaan prestasi belajar IPS.

Asyhar mendefinisikan media audio visual adalah jenis media yang digunakan dalam kegiatan pembelajaran dengan melibatkan pendengaran dan penglihatan sekaligus dalam satu proses atau kegiatan. Kelebihan media audio visual ini adalah dapat menyalurkan pesan verbal dan nonverbal yang mengandalkan baik penglihatan maupun pendengaran. ${ }^{7}$ Hal inilah yang menyebabkan ketika siswa dibelajarkan dengan metode audio visual pesan yang verbal maupun non verbal dapat dengan mudah diterima dan diserapkan oleh siswa yang belajar. Kelebihan inilah yang kemudian dioptimalkan ketika pembelajaran menggunakan media audio visual. Azhar Arsyad juga mengemukakan, bahwa media audio visual dapat memperlancar pemahaman dan memperkuat ingatan, menumbuhkan minat siswa dan dapat memberikan hubungan antara isi pelajaran dengan dunia nyata. ${ }^{8}$ Sehingga sangat dimungkinkan penggunaan media audio visual mendorong peningkatan dalam perolehan hasil belajar siswa.

Dari inteview dengan siswa diperoleh ganbaran, bahwa siswa merasa mudah dalam belajar IPS dengan menggunakan mediaa audio visual karena merasa lebih mudah untuk memahami materi. Kemudahan ini dirasakan karena siswa bisa menyesuaikan materi dengan gambar atau situasi riil di lapangan karena materi mudah di visuaalkan dengan gambar. Sesuatu yang riil akan mudah diingat dan dipahami oleh si belajar.

\footnotetext{
${ }^{6}$ Nira Elphira dan Anik Gufron, " Pengaruh Penggunaan Media Power Point Terhadap Minat dan Hasil siswa kelas IV SD”, Jurnal Inovasi Teknologi Pendidikan Vol 2, No 1, April 2015.

${ }^{7}$ H. Rayandra Asyhar, Kreatif Mengembangkan Media Pembelajaran (Jakarta: Gaung Persada Press, 2011), 45
}

${ }^{8}$ Azhar Arsyad, Media Pembelajaran (Jakarta : PT Raja Grafindo, 2014), 89 
Siti Khoiriyah

Moh Sutomo

Dari pembahasan diatas maka dapat disimpulkan bahwa media audio visual dapat membantu guru untuk mempermudah menyampaikan isi dari materi pembelajaran kepada siswa. Media audio visual dengan beberapa kelebihannya juga dapat membuat siswa antusias dalam menerima materi pembelajaran. Interaksi antara guru dan siswa juga akan semakin membaik. Dengan, penggunaan media pembelajaran audio visual ini siswa mudah menyerap materi yang disampaikan, hal ini akan berpengaruh pada hasil belajar siswa yang lebih baik. Jadi semakin sering guru menggunakan media audio visual dalam pembelajaran maka semakin sering guru menggunakan media pembelajaran audio visual dalam kegiatan pembelajaran maka semakin tinggi hasil belajar yang diperoleh.

\section{DAFTAR PUSTAKA}

Arsyad, Ashar. 2013. Media Pembelajaran. Jakarta : PT Raja Grafindo Persada. . 2011. Media Pembelajaran. Jakarta: PT Raja Grafindo Persada.

Asra, dkk. 2007. Komputer dan Media Pembelajaran di SD. Jakarta: Direktorat Jendral Pendidikan Tinggi.

Asyhar, H. Rayandra. 2011. Kreatif Mengembangkan Media Pembelajaran. Jakarta: Gaung Persada Press.

Ahmad Toha Putra. 2001, Al-qur'an dan Terjemahnya (Transliterasi Arab dan Latin) Model Berbasis. Semarang: CV, Asy Syifa.

Sudjana dan Rivai. 2001. Media Pengajaran. Bandung: Sinar Baru Algen Sindo.

Sugiyono. 2016. Metode Penelitian Kuantitatif, Kualitatif, dan R\&D. Bandung : Alfabel.

Susanto, Ahmad. 2013. Teori Belajar dan Pembelajaran di Sekolah Dasar. Jakarta: Kencana Prenada Media Group.

Trianto.2011. Pengantar Penelitian Pendidikan Bagi Pengembangan Profesi Pendidikan Dan Tenaga Pendidikan. Jakarta : Kencana Prenada Media Group. 